\title{
An Annotated Bibliography of the Translation Studies Books Published in 2019: Part I
}

\author{
SUBHA CHAKRABURTTY
}

Asimakoulas, Dimitris. 2019. Rewriting Humour in Comic Books. Singapore: Palgrave Macmillan.

Humour sometimes is the most unforgettable feature of a story and readers find it catchy from a very young age. Humour is an element in the narratives that stick; the characters, the plot lines, the graphics all lend a synesthetic effect in the minds of the readers. Divided into five broad chapters, the first chapter revolves around Aristophanes' play adaptations and raises the relevant questions - who are these translators, what are their methods of translating? To answer these questions, Dimitris Asimakoulas have used semi structured interviews. The publishers and translators have revealed through these interviews how the rewriting bridges gap between the classic text and the contemporary take on it including its political themes. The second chapter delineates the social and historical context of this genre using Lefevere's theory of rewriting as its theoretical framework. Chapter three focuses on the five plays of Aristophanes and their respective comic book adaptations, namely Acharnians, Peace, Women at the Thesmophoria, Frogs and Assembly of Women. The chapter examines the creative interventions by the translators with regard to the character sketch and the plotlines (for example, Peace which has a play within the comic). The penultimate chapter studies the four aspects -comic tone, comic suspense, comic surprise and comic characterization to understand the English translations of the Greek originals. Chapter five delves deep into the comic characters problematising the comic hero.

Desblache, Lucile. 2019. Music and Translation. London: Palgrave Macmillan. 
Professor Desblache's Music and Translation brings together two varied disciplines - Music and Translation Studies which make it a challenging but at the same time an exhilarating project. The text is inclined towards translation studies but with a strong interest to scholars in the field of music. The book aims to explore not only how musical texts are translated but also how translation studies and music are related to one another. It focuses on the music of the twentieth and twentyfirst centuries with a special emphasis on the United Kingdom besides deriving examples from across the globe. The book is divided into three parts. The first part delineates the definitions and concepts of Translation Studies and Music. The second part revolves around which musical texts are translated and most importantly how. The third part analyses the translational power of music as music emerges from different sounds only to be interpreted correctly. It could create an understanding between the human and the non-human entities and ever so needed in this changing and challenging times.

GARCIA, AdOLFO M. 2019. The Neurocognition of Translation and Interpreting. Amsterdam: John Benjamins Publishing Company.

Since centuries, translation and interpretation studies have been addressed from many different perspectives. Thus far, the approaches to cognitive translation and interpretation studies have been non-neural. These approaches hardly draw on the brain cells informed data and rely mostly on linguistic results. A new trend, however, has emerged wherein human cognition is considered. A common question therefore arrives, "Why translation and interpreting studies should be concerned with neurocognition at all?" The text counters this by asking an even more important question, why should it be stressed to situate translation in the brain cells "when cognitive translation seem to be moving away from a strict experimental paradigm 
towards a view of cognition that relies on contextual factors?" It is definitely a defiant step for any author to situate the study far from the conventional domain and portray the significance of locating translation in the brain cells. The text takes on an ambitious journey in looking at translation and interpretation studies from the neurocognitive point of view. Divided into eight chapters, the book highlights on the "unknown knowns" and not the known unknowns!

Gutierrez, Lucia Pintado; And Alicia CAstillo VillanueVA. (eds.). 2019. New Approaches to Translation, Conflict and Memory. Switzerland: Palgrave Macmillan.

The text is a collection of essays that revolve around translation, conflict and memory studies. Delving deep into the socio-cultural representations of the Spanish Civil War and the Franco Dictatorship, it navigates the importance and the effect of translation in Spain and beyond. Spain has been the seat of translation during the 1930's. The Spanish civil war was a perfect example of translation as both a product as well as a process. The war may have been Civil in name but the idea working behind it was transnational and not national. Socialism, fascism, liberalism were all pan-European undercurrents that were constantly influencing the thoughts and decisions of the parties in conflict. The other sites such as Rwanda or Cambodia also bear testimony to such horrific narratives and therefore a reminder of the conflict between memory and translation, silencing of words and authors. The text includes direct reports from the war zones, audiovisual productions. The contributors of the text have paid enough attention to examine the process of translation through a contemporary lens.

Marco, Marcella De; And Piero Toto. (eds.). 2019. Gender Approaches in the Translation Classroom. London: Palgrave Macmillan. 
This text is divided into eleven chapters with the introductory chapter and the concluding chapter written by the editors, Marcella De Marco and Piero Toto. The other nine chapters have been contributed by scholars and professors of Translation Studies. The book sees translation as a practice to incorporate more of social changes in such a way that the gender bias questions and analysis could be altered. Gender as a discipline affects both the public as well as the private sphere. The text further tries to attempt at increasing the gender awareness, through the use of linguistics in the translation classrooms. Ever since gender equality has taken the centre stage, thanks to the large organizations such as the Commonwealth and International Labour Organization, gender training has constantly been one of the top priorities and need of the hour. The different topics covered in this book are audiovisual translation, pedagogy, interpreting, curriculum design, legal translation and the translation of advertising.

Meng, Lingzi. 2019. Gender in Literary Translation. Singapore: Springer.

The text is a corpus-based study of the English translation of Chenzhong De Chivang. Ever since the women's movement, the issue of gender with language has been intrinsically linked. Through the impact of post-structuralism on gender studies, newer perspectives of viewing gender as a context based performative medium has been established. It's multiple and fluid nature has helped in deconstructing the previous essentialist notions of gender. As a result, texts have been translated or re written in a certain way, in a given context. Meng has aimed to explore gender construction through the post-structuralist lens. The author has done a corpus-based research of the English translations of the Chinese novel by Chenzhong De Chibang. One translation has been done by a man and the other by a woman, analysing thereafter the 
specific nuances found in the methodology and language of the man vis-a-vis the woman translator. She has further delved into the naming of the character, footnoting, translational omission and prefacing. Finally, the texts have been analysed keeping in mind the different gendered subjectivity and ascertained by social structures within which power resides.

PARLOG, ABA-CARINA. 2019. Intersemiotic Translation. Singapore: Palgrave Macmillan.

The text on Intersemiotic Translation revolves around the means of finding meanings through the different forms of coded information. The first part interestingly uses signs and colours to understand a particular text. For example, in $A$ Midsummer Night's Dream, the colour black symbolises something evil, "fog as black as Acheron". While in some other context, black symbolises a lack of colour or emptiness, as Rosalind in As You Like It feels, "All the pictures fairest lin'd/ are but black to Rosalinde". The next part includes theoretical approaches on multimodality and scholarship on communication. It is comprehended by the act of transmutation. Intersemiotic translation and multimodality can be examined in various cases in order to find meanings or to make it to a new system of meanings through these semiotic types - the signal, the indicator, the expression and the gesture which evolve from a cause-effect relationship.

Rizzi, Andrea; Birgit LANG; AND ANTHONy Pym (eds.). 2019. What is Translation History? Switzerland: Palgrave Macmillan.

Translation Studies students and scholars have lamented since the early 1990's for a detailed history of the 'history' of Translation Studies. Literary historians like Lawrence Venuti and Rita Copeland have worked on Foucault's concept of "genealogy" to understand the historical attitude to translation - transparency, assimilation and imitation to name a few 
among the others. While on the other hand, French sociologists like Bruno Latour have brought in the key concepts such as social capital and habitus. In the later years, the United Kingdom and North American historians have contributed significant amount of scholarship by "situating translators at the interface" between the publication and consumption of the books. Most contributions to translation history have been very region/ culture/language specific. However, in the recent years research in tracking the history of translation in the east and west beyond specific region has been made successful. There are dedicated journals that address translation and interpretation studies, namely translation and gender, translation and travel, methodologies, etc.

SandBAnK, Shimon. 2019. The Wall and the Arcade. Chicago: Sussex Academic Press.

Sandbank after extensively translating poetry from English and German to his native tongue, Hebrew feels the desperate urge to turn the practice into theory. Reading much about the translation theories he stumbles upon Walter Benjamin and his seminal essay "The Translator's Task". Benjamin too went through the same phase as Sandbank while translating the enormous oeuvre of Charles Baudelaire, the French poet, art critic and essayist. While Sandbank contends that he would never be able to be an original writer/ poet because he would only be good at rewriting others' work so that it becomes highly acceptable to the Hebrew audience/ readers; Benjamin however denies "acceptability", focusing on breaking the barrier of the 'mother tongue' and advancing towards the "Pure Language". The Wall and the Arcade raises many intriguing philosophical debates about writing, language and translation through the constant reference of the abovementioned Benjamin's essay. 
Shachar, HiLA. 2019. Screening the Author. Singapore: Palgrave Macmillan.

The literary biopics have been exceedingly popular since the early 1990s. Unlike today, literary biopics in the past have only been viewed as a cinematic biopic and costume drama. They were also termed as "heritage" dramas, thus subverting their focus on the persona of the author. The text contends to analyse the language and cultural tropes used in literary biopics, not just of the highly saleable and anthologized authors like Shakespeare and Jane Austen but of the Beat writers as well of whom not much work has been done yet. The book earnestly seeks to broaden the horizon of what is usually considered as an adaptation, heritage, period films and biopics. The author further categorises biography, period drama and biopic as per their contexts and forms an understanding of the genre based on the definition of the earlier literary biopics and the contemporary trends.

Sulaiman, M. Zain; AND Rita WiLson. (eds.). 2019. Translation and Tourism. Singapore: Springer.

With the ever-increasing globalisation and enhanced movability/adaptability, tourism, especially international tourism has emerged as a significant economic sector in the world economy. With the rise of the "experience economy", the term coined by Harvard Business Journal in the year 1998, the tourism industry is larger than ever. The diverse and constant expansion of the tourism industry has led to discovering newer destinations besides the traditional, popular ones like Europe, Canada and China. Travel and tourism are a common topic of research for the students and scholars of Anthropology, Psychology and Sociology. However, it has also perked the interests of the Translation Studies scholars in recent years as it has emerged as an important site for the scholarship of translation and intercultural communication. 
The challenges though of circulating different linguistic materials to promote the industry across the borders remain less researched. The book targets to look into the problems of the poor circulation of the translated tourism promotional materials (TPMs) and proposes a sustainable solution of endowing highest impact on the industry and the economy. It works with the cultural-conceptual translation (CCT) model which aids in effective translation strategies and provides a proper framework for quality practices in TPM translation.

Tipton, Rebecca; And Louisa Desilla. (eds.). 2019. The Routledge Handbook of Translation and Pragmatics. London: Routledge.

Pragmatics is the study of using signs which is inherently bound to a context. It only seems natural that Pragmatics and Translation Studies are interlaced as both these disciplines are context based. The book explains the concept of pragmatics through the other interconnected concepts of semiotics and semantics and further delineates its influence on the theories in Translation Studies. The text is divided into three parts, the first part being "Influences and Intersections" where the basic concept of pragmatics and its various theories have been introduced. The second part, "Methodological Issues" emphasises on the corpus-based study especially the experimental approaches. "Applications", the third part is further subdivided into various themes focussing on studies of translation and interpreting which includes British sign languages, dubbing, pragmatics inspired fictions and films (subtitling).

VALDEOn, Roberto A.; AND Africa VidAl. (eds.). 2019. The Routledge Handbook of Spanish Translation Studies. London: Routledge.

The Handbook of Spanish Translation Studies edited by Valdeon and Vidal offers a detailed analysis of the Spanish 
translation history. The lands of Spain and broadly the Iberian Peninsula have long been the site of striking conquests and invaders, starting from the Celts, the Greeks to the Romans and the Islamic rulers. Translation therefore has always played a significant role in the history of Spanish kingdom. The Handbook aims to provide a broad spectrum to the important role that the translators played in the history of Spain and also in the emergence of translation studies as a modern discipline. The text has twenty-four essays from scholars and professors of Translation Studies on varied topics such as Pedagogy of Translation, Linguistic Approaches to Translation, Gender and Translation, Translation of Hispanic Comics and Graphic Novels to name a few.

Wang, GuAnglin. 2019. Translation in Diasporic Literatures. Singapore: Palgrave Macmillan.

Translation has been a popular theme among the contemporary postcolonial and diasporic authors. The research by Wang who has given away his positions of deanship and directorship in university only to take up a full-time job on his passion of looking into the complexities of translating from Sino-Anglo literary encounters to the East-West mediations. The text is divided into six chapters. The first chapter attempts to delineate the "paradox of roots and routes" that exists in the scholarship of diasporic Chinese writers in the context of their culture. Chapter two revolves around the translation of the classic Chinese text, Six Chapters of a Floating Life into The Red Thread: A Love Story. Its appropriation and how the boundaries blur between the East and the West, ancient and modern, the racial lines are highlighted and addressed. The third chapter uses the theories of Deleuze and Guattari's deterritorialisation to understand the translation of Brian Castro. Chapter Four works on the anti-modernist stance of Walter Benjamin. The penultimate chapter focuses on the 
intersemiotic translation by none other than the high priests of Modern literature - Ezra Pound, Franz Kafka and Walter Benjamin. The final chapter delves deep into the "translatability" and "untranslatability" factor to emphasize on the binary oppositions of language and culture.

XIA, LiAng. 2019. A Discourse Analysis of News Translation in China. London: Routledge.

Translation studies these days are no longer restricted to just literally translating from one source text to the target text. Rather, it focuses on the socio, cultural practices. Global news transmission, as it relies on language generates a good deal of translation. This text revolves around the translation and its methodologies with regard to the most popular and circulated newspaper in China, the Cankao Xiaoxi. It is a unique newspaper as it covers stories that are translated from international news source. The book is a sound work in understanding how the Chinese media work in certain matters as Liang Xia have interviewed a lot of employees, mostly journalists in receiving the inside information. The idea of translation, especially while curating the news involves a lot of manipulation. This manipulative practice has led Xia to study the discourse of translation and how it affects the news making process in China. With an ethnographic approach, the scholarship looks into who is translating, the target audience and how is it situated in the socio-political, economic fabric of the society. The study depicts the layers of manipulation that goes while publishing this sort of a media work and how it transcends the social and ideological barriers. 